\title{
Reduction in Trace Element Mediated Oxidative Stress towards Cropped Plants via Beneficial Microbes in Irrigated Cropping Systems: A Review
}

\author{
Aydin Enez ${ }^{1,2}$, Lee Hudek ${ }^{1,2}$ and Lambert Bräu 1,2,*(D) \\ 1 Centre for Regional and Rural Futures, School of Life and Environmental Sciences, Deakin University, \\ Geelong 3220, Australia; aenez@deakin.edu.au (A.E.); lee.hudek@deakin.edu.au (L.H.) \\ 2 Centre for Cellular and Molecular Biology, School of Life and Environmental Sciences, Deakin University, \\ Geelong 3220, Australia \\ * Correspondence: lambert.brau@deakin.edu.au; Tel.: +61-3-9251-7055
}

Received: 20 September 2018; Accepted: 15 October 2018; Published: 17 October 2018

\begin{abstract}
Summer crops grown in Australia, including rice, cotton, and sugar cane, require high volumes of water, which is applied using irrigation systems. Yields from these crops are influenced by abiotic stressors. Fluctuations in the abiotic stressors, including soil $\mathrm{pH}$ and trace element availability, can increase levels of reactive oxygen species (ROS) in plants leading to increased oxidative stress and subsequent reduced crop growth and yield. One potential way of reducing plant ROS production and levels in these systems is through inoculation of these crops with beneficial microbes. The ability of beneficial microbes to enhance plant growth is well characterized, and it is also clear that many of them produce antioxidant enzymes. Presented in this review are the potential modes of action for microbes to reduce abiotic stress in cropped systems.
\end{abstract}

Keywords: plant abiotic stress; reactive oxygen species (ros); trace elements; plant growth promoting bacteria (pgpb); irrigation

\section{Introduction}

Plant stressors impact yields of both summer and winter crops, including canola, wheat, sugar cane, corn, cotton, and rice. The main abiotic plant stressors that impact crop growth include fluctuating temperatures, soil $\mathrm{pH}$, salinity, soil water availability (drought), diurnal cycling changes, and availability of soil nutrients [1-12]. Summer crops grown in Australia, including rice, cotton, and sugar cane, require high volumes of water, which is applied using irrigation systems. In Australia, winter crops, including canola, wheat or maize are planted in rotation with the aforementioned summer crops and grown [13-15] using the seasonal precipitation and residual moisture from the irrigation season. Summer irrigated crops are of high economic value, producing a combined export income between $\$ 5.8-6.8$ billion AUD annually [16-18], whilst their winter counterparts had an export value of $\$ 10.2$ billion AUD in 2016 [19].

The irrigation strategies for these crops can either be 'high' or 'low' depending on the crop plant being cultivated, season or soil profile $[6,15,20,21]$. High irrigation strategies primarily refer to flood irrigation (largely water inefficient), whereas low water types include subsurface drip irrigation, sprinkler irrigation, localized irrigation, and lateral move irrigation (highly water efficient) [22,23]. Currently, flood irrigation is the main practice used in Australia for delivering consistent large volumes of water to maintain a moist soil environment that propagates crop growth [24].

Throughout the growing season, irrigated soils fluctuate between aerobic and anaerobic states based on water availability in the soil. The type of irrigation strategy will also have profound effects 
on the soil temperature, soil $\mathrm{pH}$, water salinity, soil water availability (water activity), light intensity, and availability of trace elements (Figure 1) [1,24]. Thus, the influence of irrigation strategies on the abiotic characteristics of agroecosystems can lead to the formation of abiotic stress towards the cropped plants [25].

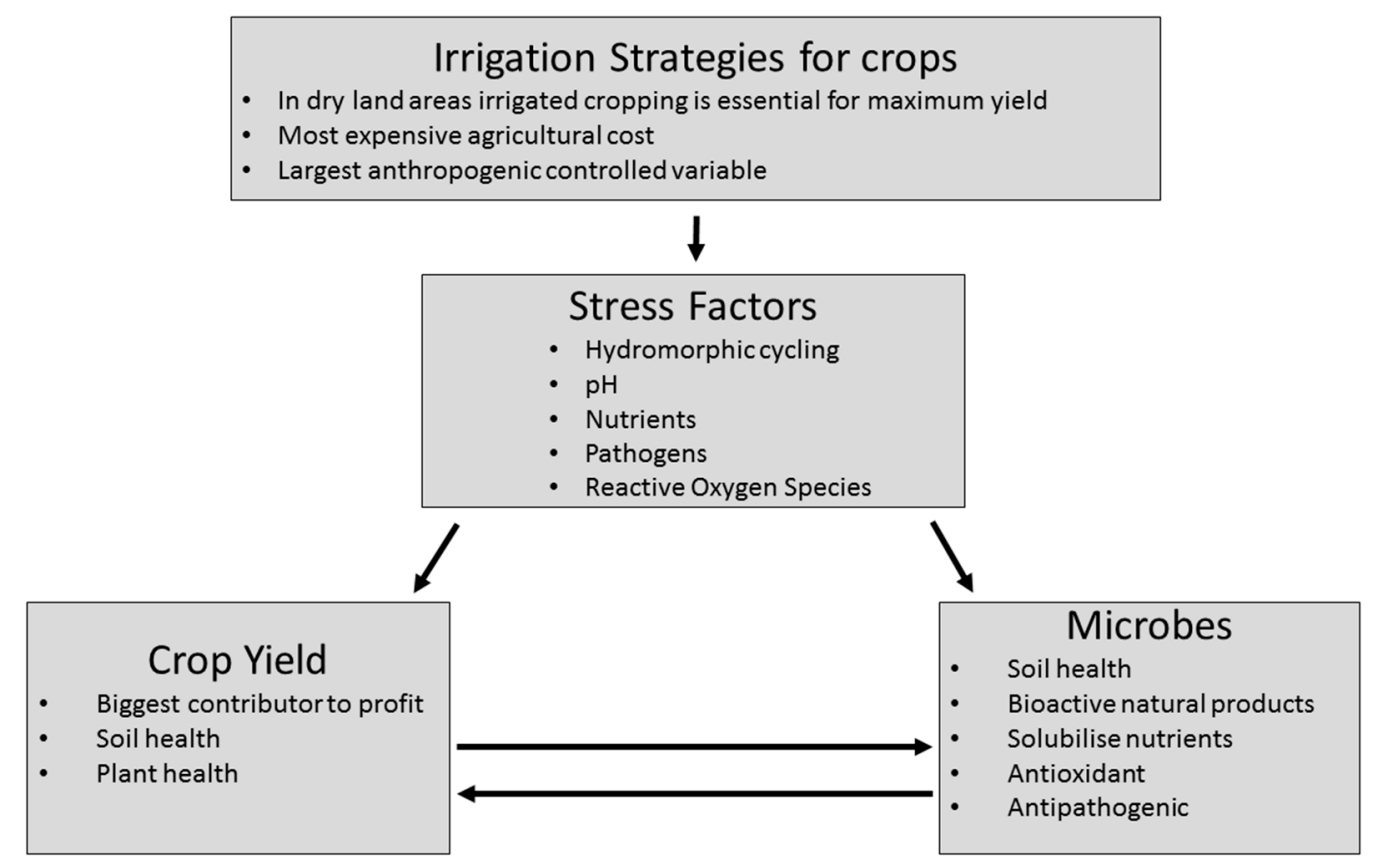

Figure 1. Irrigation strategies associated with the propagation of crops are the most expensive anthropogenically controlled variable and whilst important for maximum yield, they also have a large influence on stress formation. These stress factors include hydromorphic cycling, fluctuation in $\mathrm{pH}$, nutrient availability, pathogenic attack, and ultimately reactive oxygen species formation. These stress factors influence both crop yield and microbial diversity of soils. Crop yield is the biggest contributor to profit and relies on optimal soil and plan health. Microbes in the soil can be beneficial to plants and soil health by producing bioactive compounds, solubilizing nutrients and having anti-pathogenic activity. They also have high levels of antioxidant activity, which can potentially alleviate stress towards cropped plants inflicted by soil stress factors.

Trace element availability is an abiotic stressor that directly impacts growth and yield of cropped plants and is influenced by irrigation strategy [26]. Trace elements are found in small concentrations $\left(\mathrm{mg} / \mathrm{kg}^{-1}\right.$ or less) in the environment and include: copper $(\mathrm{Cu})$, cobalt $(\mathrm{Co})$, zinc $(\mathrm{Zn})$, iron $(\mathrm{Fe})$, nickel $(\mathrm{Ni})$, manganese $(\mathrm{Mn})$, vanadium $(\mathrm{V})$, selenium $(\mathrm{Se})$, and molybdenum (Mo). These are essential as they act as cofactors for enzymatic activities and other metabolic processes in plants [27]. Irrigation affects trace element availability by solubilizing these metals, changing soil $\mathrm{pH}$, changing soil transformation rate, and subsequent redox changes associated with soil compounds $[6,28]$.

Differences in trace element availability are observed between flooded soils and dry soils, and it is known that Zn solubility differs greatly between flooded anaerobic soils compared to aerobic dry conditions [29]. This change in trace element solubility has become a major concern for the production of rice crops as cultivation practices change. As irrigated soils dry out and become aerobic, associated $\mathrm{pH}$ and redox changes render some trace elements unavailable-referred to as 'nutrient lock out' [27,30,31]. Moreover, the bioavailability of non-essential heavy metals, including arsenic (As), cadmium (Cd) and mercury $(\mathrm{Hg})$, is also affected by changes in anaerobic/aerobic cycling, and these metals are typically more toxic at much lower concentrations compared to essential trace elements [27].

Metal levels in soil can range from less than $1 \mathrm{ppm}(0.0001 \%)$, through to $100,000 \mathrm{ppm}(10 \%)$ or higher in extreme cases [32,33]. Fluctuations of metal levels in the environment alters their availability to the biota. Generally for higher plants, the deficiency limit of essential metals, such as $\mathrm{Cu}, \mathrm{Mn}$, 
$\mathrm{Ni}$, and Zn required for normal cellular functioning and growth is: $20-30 \mathrm{mg} / \mathrm{kg}$, 200-5300 mg/ $\mathrm{kg}$, $10-50 \mathrm{mg} / \mathrm{kg}$ and $100-300 \mathrm{mg} / \mathrm{kg}$, respectively [34]. When concentrations of these metals exceed these trace-levels they start to reduce cellular metabolism leading to toxicity, and in the most drastic case the death of the plant $[21,23]$.

For most uncontaminated soils, the levels of trace metals $\mathrm{Co}, \mathrm{Cu}, \mathrm{Mn}, \mathrm{Ni}$, and $\mathrm{Zn}$ are in the ranges of $0.08-29 \mu \mathrm{g} / \mathrm{L}, 0.5-135 \mu \mathrm{g} / \mathrm{L}, 25-8000 \mu \mathrm{g} / \mathrm{L}, 0.2-150 \mu \mathrm{g} / \mathrm{L}$ and $0.1-750 \mu \mathrm{g} / \mathrm{L}$, respectively [35]. Optimal levels of trace elements such as $\mathrm{Fe}, \mathrm{Mn}, \mathrm{Cu}$, and $\mathrm{Zn}$ are required for both catalase and superoxide dismutase antioxidant activity [36]. These enzymes break down both $\mathrm{H}_{2} \mathrm{O}_{2}$ and superoxide that forms from oxidative stress, respectively. When levels of free metals become too high, rather than act as co-factors, these metals become cytotoxic and cause damage to plants through the influence of physiological changes that result in ROS formation and eventual oxidative damage towards plants [37]. However, sub-optimal levels of trace elements can lead to oxidative stress being unregulated, as the activity of enzymes that break-down ROS (e.g., catalase) may be inhibited without the metal ion co-factors, leading to the loss of homeostatic control of ROS [38].

\section{Physiological and Biochemical Impacts of Oxidative Stress towards Cropped Plants}

The two primary ways abiotic stressors cause oxidative stress towards plants is either by creating imbalance in the metabolic pathways or a reduction in the efficiency of antioxidant enzymes [39-41].

Abiotic stressors can reduce growth and metabolism by increasing unmoderated production of free-radicals, such as reactive oxygen species (ROS) [3,4,42]. Free radicals that form after exposure to these abiotic stressors, such as $\mathrm{OH}^{-}$, are capable of damaging the heterocyclic bases and the sugar-phosphate backbone of DNA. Other ROS, including $\mathrm{H}$. free radicals and free electrons, react with the double bonds in DNA [43]. Free radicals can damage lipids and other cellular components by oxidizing them (via attack of paired electrons), and are directly linked to a reduction in cellular viability leading to oxidative stress [2,44]. On a farming scale, the impacts of oxidative stress on crops can potentially result in large losses of biomass, yield, reduced seed vigor, reduced germination efficiency, improper plant development, loss of plant viability and ultimately, reduced economic benefit to the grower $[1,45,46]$.

Most abiotic stressors inflict oxidative damage towards cropped plants by inducing the overproduction of free radicals as part of essential metabolic processes, including photosynthesis. These abiotic stressors can include shifts in diurnal cycling, where a cropped plant is exposed to fluctuating light intensities [47], and drought conditions in soils where osmotic stress impacts the crop [48].

During photosynthesis, when exposed to high levels of light, the electron transport chain becomes over-reduced and harmful ROS species are produced [49]. Similarly, fluctuations in temperature lead to stress development in plants. Low temperature stress reduces seed vigor, growth, and metabolic activity [50], whilst high temperature exposure in plants results in leaf membrane degradation and lipid peroxidase damage linked to increased ROS activity, as observed in Jatropha curcas (Nettlespurge) [51]. Variances in water availability lead to osmotic stress (the reduction in turgor and water potential of plants), sufficient to disrupt normal metabolism and induce desiccation of plant tissues [52,53]. In Brassica napus L. (canola) leaves, growth reducing oxidative damage caused by reduced water availability has been observed to occur at around $-1.5 \mathrm{MPa}$. This is due to increased lipid peroxidation, reduced phospholipid and galactolipid content of leaf cells, and altered leaf structure [54].

Trace element availability has varying effects on oxidative stress in cropped plants and is the abiotic stressor that has the highest influence on antioxidant enzyme activity. The bioavailability of trace elements for cropped plants are heavily influenced by soil factors including: soil $\mathrm{pH}$, soil organic matter (SOM) content, and $\mathrm{Mn} / \mathrm{Fe}$ oxyhydroxide presence [55], indicating that irrigation and soil properties are ultimately the drivers of trace element induced oxidative stress towards cropped plants. 


\section{The Impact of Trace Element Availability on the Induction of Oxidative Stress in Cropped Plants}

The availability of metals fluctuates between anaerobic (high moisture) conditions and aerobic (low moisture) conditions. Increased metal solubility leads to higher levels of bioavailable metals in soils leading to potentially growth-inhibiting toxicity in plants. Low metal solubility results in nutrient lockout of some trace elements, inhibiting plant growth and exacerbating other stressors on the crops $[1,24,31]$. The tendency for flood irrigation to solubilize more metals than in drier soil conditions is suspected to be due to increasing overall soil $\mathrm{pH}$, increasing metal precipitation with chemical compounds such as sulphides and increased concentrations of Fe oxides [6].

Increasing heavy metal availability is also of concern to crop health and this fluctuates with irrigation strategy. Under flooded irrigation conditions, AS bioavailability increases, which in turn can lead to higher uptake of As by plants resulting in reduced plant growth or even death. Likewise, the use of sprinkler irrigation has shown to reduce concentrations of As in the soil; however, it has been shown to increase concentrations of $\mathrm{Cd}[21,23]$.

The mode of action for free metal mediated oxidative stress towards living organisms arises from chemical reactions that catalyze metabolic products into ROS. For example, the Haber-Weiss reaction is the catalysis of superoxide and hydrogen peroxide to harmful hydroxyl radicals by transition metals, mostly $\mathrm{Fe}$ and $\mathrm{Cu}$ [56]. It incorporates the Fenton reaction, which occurs when $\mathrm{Fe}^{2+}$ or $\mathrm{Cu}^{+}$reacts with hydrogen peroxide (e.g., produced in the mitochondrion as a cellular respiration by-product) into harmful hydroxyl radicals [57]. The Fenton reaction can be exacerbated when organisms are under $\mathrm{Cu}$ stress. Whilst $\mathrm{Cu}$ is a cofactor for SOD, higher SOD activity leads to higher levels of $\mathrm{H}_{2} \mathrm{O}_{2}$ being produced. This particular situation has been observed in some bacterial species including Staphylococcus aureus [58], Mycobacterium tuberculosis [59], and Pseudomonas aeruginosa [60].

For plants, the major source of $\mathrm{Cu}^{+}$is found in the roots, whilst $\mathrm{Fe}^{2+}$ and $\mathrm{Mn}^{2+}$ are primarily found in shoots, where they are heavily involved in photosynthesis [61]. Excessive $\mathrm{Cu}^{+}$levels in the soil can lead to localized Fenton reactions within the root walls, forming toxic hydroxyl radicals, causing chlorosis and ultimately reducing biomass [61]. Similarly, excessive soil $\mathrm{Fe}^{2+}$ or $\mathrm{Mn}^{2+}$ levels may lead to an imbalance in photosynthetic enzyme activity, resulting in an excessive production of hydroxyl radicals and subsequent photoinhibition [61].

Some bacterial species have been shown to combat free metal oxidative stress by substituting enzymes that require $\mathrm{Fe}^{2+}$ as a cofactor for homologues that have no requirement for it. For example, Streptococcus pyogenes has been demonstrated to substitute an Fe-containing ribonucleotide reductase (RNR) enzyme for an Fe-free homologue for DNA synthesis. Similarly, E. coli has been shown to be able to use $\mathrm{Mn}^{2+}$ as a substitute for $\mathrm{Fe}^{2+}$, as a cofactor for its RNR enzyme [62].

Excessive levels of other free transition metals, including $\mathrm{Cd}, \mathrm{Co}, \mathrm{Ni}$, and $\mathrm{Zn}$ are also known to cause stress challenges towards cropped plants. In Spinacia oleracea L. (spinach), $500 \mu \mathrm{M}$ treatments of spinach for 10 days with each metal resulted in chlorosis and reduced the activity of CAT. Excess Cd, $\mathrm{Co}$, and $\mathrm{Ni}$ also saw an increase in lipid peroxidation [63]. High concentrations of $\mathrm{Zn}, \mathrm{Co}, \mathrm{Ni}$, and $\mathrm{Cd}$ have been shown to significantly interfere with physiological and genetic Fe homeostasis mechanisms, mimicking Fe-deficiency in plants such as $A$. thaliana [64]. The subsequent metal toxicity and Fe-deficiency reduces root elongation and growth, shoot weight, and chlorophyll content of leaves [64]. Excessive levels of $\mathrm{Cu}, \mathrm{Co}$, and $\mathrm{Ni}$ can also lead to oxidative stress by causing cytotoxicity and injury to plants through the production of ROS, and subsequent oxidative damage [37].

In contrast, a lack of trace element availability reduces metabolic function, as many enzymes and cellular processes require particular trace elements to maintain optimal activity for growth, reproduction, and defense [65]. In particular, plants can become susceptible to oxidative stress if particular trace elements become unavailable, as antioxidant defense mechanisms require these to function, such as Fe or Mn for catalases (CATs), or both $\mathrm{Cu}$ and $\mathrm{Zn}$ for superoxide dismutases (SODs) [66-68]. 
Ultimately, plant cells must have protection against free radical damage, balancing ROS production to allow for healthy growth whilst maintaining respiration and energy production [69]. To combat the challenges to growth and survival presented by abiotic stress, they have several antioxidant mechanisms in place, including CAT, SOD, ascorbate peroxidase, glutathione, and phytochelatins to reduce the production of ROS [51,69]. These enzymes act to reduce the accumulation of ROS and their activity is tightly regulated [51,69]. For example, in Jatropha curcas (Nettlespurge), antioxidant enzyme activity increases under heat stress to match increased $\mathrm{H}_{2} \mathrm{O}_{2}$ production, and the ability to limit ROS activity is linked to efficient detection and increased expression of genes in response to the stressor [51].

\section{Plant Antioxidant Defenses against Oxidative Stress Challenges}

Catalase enzymes oxidize $\mathrm{H}_{2} \mathrm{O}_{2}$ and are the most characterized antioxidant proteins [70,71]. In plants, two types of catalases exist, monofunctional catalases and bifunctional catalase-peroxidases [70,72]. In Arabidopsis thaliana, a small gene family encodes three CAT proteins, known as Cat1, Cat2, and Cat3, and this is typical of most plants, including B. napus (canola) [73]. The Cat1 enzyme is predominantly found in vascular tissue, Cat2 is largely found in leaf tissue and is primarily expressed in the morning period, and Cat 3 is primarily abundant in seedlings and heavily involved in removing $\mathrm{H}_{2} \mathrm{O}_{2}$ from glyoxysomes, acting primarily in the evening period [74].

Some abiotic stressors reduce the efficiency of antioxidant enzymes. Saline soils induce stress towards cropped plants and lead to oxidative damage by reducing the activity of antioxidant enzymes. This occurs when the cellular balance of $\mathrm{Na}^{+}$and $\mathrm{K}^{+}$is disrupted [75], allowing for unregulated production and accumulation of ROS in plant tissues. Soil $\mathrm{pH}$ can influence the sensitivity of cells to ROS under either low or high $\mathrm{pH}$ conditions by changing bioavailability of trace metals, meaning they are either more or less available for uptake by plants [76]. Altered soil $\mathrm{pH}$ has been shown to limit bioavailability of trace elements, including $\mathrm{Zn}$ and $\mathrm{Cu}$, which are essential for SOD activity in most plants $[69,77]$. Ultimately, low soil nutrients indirectly result in oxidative damage to plant cells, as the activity of enzymes that break-down ROS may be inhibited without the metal ion co-factors, hence allowing ROS to accumulate to deleterious levels [38].

High trace metal solubility is also detrimental to crop growth. Plants produce a glutathione (GSH, organic acid antioxidant that plays a role in reducing the impact of endogenous and exogenous ROS) [78], in response to elevated trace metal stress [37]. Plant phytochelatins work with GSH to chelate the metals to reduce toxicity impact. Glutathione then reduces $\mathrm{H}_{2} \mathrm{O}_{2}$ produced as a result of heavy metal exposure [37,78].

Whilst plants have antioxidant defense systems to deal with abiotic stress challenges, these systems are often limited in their ability to combat abiotic stress in broad-acre cropping systems. This is due to water and nutrient scarcity, as well as increasing temperatures due to climate change [79]. A potential way to promote crop plant stress tolerance is to utilize bacterial inoculants with high abiotic stressor tolerance, which may be able to provide a protective benefit for cropped plants [80].

\section{Can Bacterial Antioxidant Activity Reduce Oxidative Stress towards Cropped Plants?}

Plant growth promoting bacteria (PGPB) are microbes that form part of the plant holobiont [81]. They are found in the rhizosphere (the region of soil directly surrounding the roots), and are able to enhance plant growth through increased nutrient availability, production of plant growth hormones, and by providing protection from pathogens [81-83]. Well characterized bacterial plant growth promotion activities include: Nitrogen (N) fixation [84], 1-Aminocyclicpropane-1-carboxylase (ACC) deaminase activity (reduction of ethylene induced stress signaling) [85], increased phosphate solubilization [86], indole-3-acetic acid production (IAA - cell elongation and cell growth factor) [87], and pathogen suppression [81].

Bacteria have their own antioxidant enzymes for dealing with oxidative stress. Bacterial catalases, like those of plants, are also classified as monofunctional (HPII) or bifunctional (HPI) catalases, 
as well as a third group of Mn-catalases [70]. The common catalase enzymes in bacteria are KatA, KatB, KatC, KatE, KatG, and KatM [70,88]. Bifunctional catalases (HPI) are generally activated when initially challenged by oxidative stress, whereas monofunctional catalases (HPII) are utilized as the cells grow into stationary phase [70]. Some soil bacteria, including Pseudomonas fluorescens, have high antioxidant and CAT activity, potentially being able to remove excess $\mathrm{H}_{2} \mathrm{O}_{2}$ from the rhizosphere, produced during photosynthesis by plants or from abiotic stressors [89,90].

Mn-Catalases lack a heme prosthetic group and instead contain a dimanganese cluster [70]. These catalases are known to be important in reducing stress associated with abiotic stress factors, including Fe deficiency, microaerophilic environments, temperature fluctuation, high saline environments, desiccant conditions, and exposure to chemicals such as cyanide [91,92]. Cyanobacteria from the genus Anabaena (known rice biofertilizers) have been shown to tolerate oxidative stress induced by high levels of salt and desiccation via their KatB Mn-CAT enzyme [92].

Bacterial CAT enzymes serve to reduce ROS accumulation associated with stressors rather than mediating, as both stressor reducers and intracellular signaling molecules (as seen in plants) [70]. The root nodule bacterium Sinorhizobium meliloti utilizes KatA, KatB, and KatC to cope with the production of $\mathrm{H}_{2} \mathrm{O}_{2}$ generated by bacterial $\mathrm{N}$-fixation [89]. In S. meliloti, KatA activity primarily increases in response to exogenous $\mathrm{H}_{2} \mathrm{O}_{2}$ exposure, whilst KatC activity increases in response to abiotic heat and salinity stress [89]. The KatB enzyme is constitutively expressed throughout the whole growth period of the bacteria as an initial defense against oxidative stress [89]. In addition to reducing oxidative stress, S. meliloti utilizes catalase and other antioxidants to form symbioses with legumes, including Medicago sativa (alfalfa) [93], as part of the symbiosis process requiring the breakdown of plant produced $\mathrm{H}_{2} \mathrm{O}_{2}$ for nodule organogenesis [93].

Bacterial inoculants have also been shown to increase the antioxidant activity of plants when exposed to drought stress. Leaves of Lactuca sativa L. (Lettuce) were inoculated with Pseudomonas mendocina Palleroni, and either the mycorrhizal fungi Glomus intraradices or Glomus mosseae, or alone. The highest amount of CAT activity was observed in the P. mendocina-inoculated plants grown under severe stress conditions. Under moderate drought conditions, total peroxidase and CAT activity increased with bacterial and fungal inoculation, whilst SOD activity decreased [94], suggesting that these beneficial microbes could be used to alleviate oxidative stress in the lettuce.

While many soil microbes have the potential to enhance plant growth using antioxidants, some plant pathogens exploit their antioxidant systems during infection. Plants will use ROS as defense mechanisms to stop a pathogen from successful infection, often by releasing $\mathrm{H}_{2} \mathrm{O}_{2}$ into the environment or using oxidative burst $[40,95,96]$. For the proteobacterium Xanthomonas citri, enhanced production of KatG allows it to deal with the challenge of oxidative burst by citrus plants during infection of leaves [97]. It also allows for protection from UV radiation and subsequent biofilm formation [97]. Interestingly, $\mathrm{KatG}$ also confers resistance to microbicidal $\mathrm{H}_{2} \mathrm{O}_{2}$, and promotes virulence of Actinobacter spp. towards humans [98], suggesting that this bifunctional KatG enzyme may have a specialized role in defense and virulence for bacterial species $[70,97,98]$. As a bifunctional catalase, KatG has been shown to interact with other substrates such as guaiacol [70], and in M. tuberculosis infection in mammals, it is able to inactivate the anti-tuberculosis drug isoniazid [99].

Plants need to balance ROS production to allow for healthy growth, whilst maintaining respiration and energy production [69]. When grown under ideal conditions or moderately stressful conditions, plants reduce levels of ROS through CAT, SOD, ascorbate peroxidase, glutathione, and phytochelatin activity [51,69]. Under constant high stress from either insufficient nutrient availability or over exposure to high levels, these plants systems become insufficient and plant growth and prosperity is lost with plant death being the final outcome. One of the potential ways oxidative stress in cropped plants could be reduced is through inoculating plants with a beneficial microbe, which has the capacity to produce high levels of peroxidase/catalase enzymes that may directly reduce the oxidative stress in the plants through their interactions. Bacteria can also be highly capable of solubilizing nutrients from their environment and making them available through their production of siderophores. In nutrient scarce 
conditions, some rhizospheral bacteria produce siderophores that chelate Fe previously unavailable for plant uptake, and deliver them to plants enabling both plant and bacteria to thrive $[100,101]$.

Many bacteria are highly adept at tolerating fluctuation in trace metal availability. For example, in the model system Nostoc punctiforme, the highest non-toxic levels of trace elemental tolerance for $\mathrm{Co}, \mathrm{Cu}, \mathrm{Mn}, \mathrm{Ni}$, and $\mathrm{Zn}$ were determined to be $2 \mu \mathrm{M}, 0.5 \mu \mathrm{M}, 500 \mu \mathrm{M}, 1 \mu \mathrm{M}$, and $18 \mu \mathrm{M}$, respectively [102]. However, for most bacterial cells, total intracellular trace metal levels are observed in the millimolar range $\left(10^{-3}\right)$. Despite intracellular levels being very high, levels of trace metals that promote active uptake and efflux channels are usually in the femtomolar range $\left(10^{-15}\right)$. Bacterial cells are able to combat the stress challenges presented by high concentrations of metals, such as $\mathrm{Zn}$ or Mn, by regulating efflux transporters embedded in the cytoplasmic membrane, hence excluding the metals from the intracellular environment and overcoming potential toxicity effects [103].

Although the bacteria increase the availability of metals to plants when they have limited access to them, they can help the plants meet their requirement to have ideal functioning of their own systems and enzymes - such as the aforementioned ROS reduction systems (CAT, SOD, ascorbate peroxidase, glutathione, and phytochelatin) listed above. In environments with toxic levels of trace elements, rhizospheral bacteria can protect plant roots from stress by acidifying, chelating, precipitating, complexing, or inducing redox reactions that reduce toxicity of those metals [104]. Under high environmental metal conditions, bacteria present in the soil may provide a buffering effect; where the metals will bind with high affinity to the bacteria cells (predominantly by charge with the cell walls) potentially reducing their direct availability to plants, therefore indirectly reducing oxidative stress towards cropped plants [102,105].

Bacteria isolated from heavy metal polluted environments have been shown to reduce toxic impacts of metals and even enhance plant growth. The Cu-resistant bacterium Providencia vermicola has been shown to protect lentils from oxidative damage when exposed to high $\mathrm{Cu}$ soil levels-both by reducing $\mathrm{Cu}$ uptake by the plants and production of indole acetic acid and siderophores [106]. Moreover, P. vermicola was able to increase root and shoot length, dry weight, and leaf size area of the lentils [106] compared to a negative control. In another study, two Zn-resistant Rhizobium leguminosarum strains were able to enhance growth of Trifolium repens (white clover) in high $\mathrm{Zn}$ conditions [107].

In nutrient scarce conditions, some rhizospheral bacteria produce siderophores that chelate $\mathrm{Fe}$ previously unavailable for plant uptake and deliver them to plants, enabling both plant and bacteria to thrive [100,101]. The PGPB isolate Chrysiobacterium spp. C138 (previously isolated from an O. sativa rhizosphere) has been shown to enhance Fe uptake in Fe-starved Solanum lycopersicum L. (tomato) [108]. Similarly, inoculation of maize seeds with siderophore-producing Pseudomonas spp. strains lead to increases in root and shoot growth, and hence larger dry weights [109]. Chemical chelators such as ethylenediaminetetraacetic acid (EDTA) are currently used to deliver trace elements to cropped plants with varying success [110]. Prolonged use is known to lead to ecotoxicological effects, as EDTA also increases the bioavailability of dangerous heavy metals in soils [111]. Ethylenediaminetetraacetic acid has also been shown to cause leaf necrotic lesions in Brassica rapa (Chinese cabbage), and to reduce root symbiosis with arbuscular mycorrhiza in Trifolium pratense (red clover) [111].

Bacterial metabolites have already been utilized for applications, including in cosmetics, as semiconductor components; and in dairy, food, and textile industries [91]. However, their use in an agricultural context as a stress reducing agent for cropped plants is relatively unexplored. Understanding the modes of action for microbial oxidative stress reduction towards cropped plants and modulating trace element availability is essential. In other instances, microbes previously identified to be plant growth promoting can induce oxidative stress towards plants in different growth systems. For instance, the P. fluorescens isolate DUS1-27 was previously shown to enhance B. napus L. (canola) growth in soil based systems; however, when grown in a hydroponic system with the plants, an oxidative stress response is observed [112]. This highlights the importance of understanding the modes of action for microbial antioxidant mediated stress reduction in plants, as changes in environment can negatively alter microbe associated molecular patterns. Importantly, 
this highlights that expanding their use requires: (1) Understanding and characterization of how these bacteria reduce oxidative stress towards plants, and (2) confirmation as to which of these are relevant under field-based conditions.

Overall, abiotic stressors including soil temperature, moisture, $\mathrm{Ph}$, and trace metal availability, all play a role in inducing oxidative stress towards irrigated cropped plants in the form of ROS. Ultimately, fluctuating trace metal availability can increase ROS production leading to increased levels of free radicals, such as hydroxyl radicals being formed. ROS imbalance in cropped plants not only reduces growth, but also reduces crop yields. The ability of beneficial microbes to enhance plant growth is well characterized and it is also clear that many of them have a high tolerance for trace metal fluctuations in the environment. Therefore, their characteristics and modes of action to reduce abiotic stress in cropped systems is worthy of further exploration to determine their potential to increase overall soil health and cropping sustainability, as well as to reduce input costs and increase yields.

Author Contributions: A.E. wrote the manuscript with expert guidance from L.H. and L.B.

Funding: This research received no external funding.

Conflicts of Interest: The authors declare no conflicts of interest.

\section{References}

1. Mittler, R. Abiotic stress, the field environment and stress combination. Trends Plant Sci. 2006, 11, 15-19. [CrossRef] [PubMed]

2. Sharma, P.; Jha, A.B.; Dubey, R.S.; Pessarakli, M. Reactive oxygen species, oxidative damage, and antioxidative defense mechanism in plants under stressful conditions. J. Bot. 2012, 2012, 217037. [CrossRef]

3. Choudhury, F.K.; Rivero, R.M.; Blumwald, E.; Mittler, R. Reactive oxygen species, abiotic stress and stress combination. Plant J. 2017, 90, 856-867. [CrossRef] [PubMed]

4. Kazan, K. Diverse roles of jasmonates and ethylene in abiotic stress tolerance. Trend Plant Sci. 2015, 20, 219-229. [CrossRef] [PubMed]

5. Cucu, M.A.; Said-Pullicino, D.; Maurino, V.; Bonifacio, E.; Romani, M.; Celi, L. Influence of redox conditions and rice straw incorporation on nitrogen availability in fertilized paddy soils. Biol. Fertil. Soils 2014, 50, 755-764. [CrossRef]

6. Zheng, S.; Zhang, M. Effect of moisture regime on the redistribution of heavy metals in paddy soil. J. Environ. Sci. 2011, 23, 434-443. [CrossRef]

7. Timsina, J.; Jat, M.L.; Majumdar, K. Rice-maize systems of south Asia: Current status, future prospects and research priorities for nutrient management. Plant Soil 2010, 335, 65-82. [CrossRef]

8. Pantano, G.; Campanha, M.B.; Moreira, A.B.; Bisinoti, M.C. Occurrence of $\mathrm{Cu}$ and $\mathrm{Cr}$ in the sedimentary humic substances and pore water from a typical sugar cane cultivation area in São Paulo, Brazil. J. Soils Sediments 2014, 14, 377-384. [CrossRef]

9. Morrison, M.J.; Stewart, D.W. Heat stress during flowering in summer Brassica (Crop Physiology \& Metabolism). Crop Sci. 2002, 42, 797-803. [CrossRef]

10. Wang, M.; Wang, Q.; Zhang, B. Evaluation and selection of reliable reference genes for gene expression under abiotic stress in cotton (Gossypium hirsutum L.). Gene 2013, 530, 44-50. [CrossRef] [PubMed]

11. Komatsu, S.; Kamal, A.H.M.; Hossain, Z. Wheat proteomics: Proteome modulation and abiotic stress acclimation. Front. Plant Sci. 2014, 5, 684. [CrossRef] [PubMed]

12. Nakashima, K.; Yamaguchi-Shinozaki, K.; Shinozaki, K. The transcriptional regulatory network in the drought response and its crosstalk in abiotic stress responses including drought, cold, and heat. Front. Plant Sci. 2014, 5, 170. [CrossRef] [PubMed]

13. Gozubuyuk, Z.; Sahin, U.; Adiguzel, M.C.; Ozturk, I.; Celik, A. The influence of different tillage practices on water content of soil and crop yield in vetch-winter wheat rotation compared to fallow-winter wheat rotation in a high altitude and cool climate. Agric. Water Manag. 2015, 160, 84-97. [CrossRef] 
14. Sprague, S.J.; Kirkegaard, J.A.; Graham, J.M.; Dove, H.; Kelman, W.M. Crop and livestock production for dual-purpose winter canola (Brassica napus) in the high-rainfall zone of south-eastern Australia. Field Crop. Res. 2014, 156, 30-39. [CrossRef]

15. Breidenbach, B.; Blaser, M.B.; Klose, M.; Conrad, R. Crop rotation of flooded rice with upland maize impacts the resident and active methanogenic microbial community. Environ. Microbiol. 2016, 18, $2868-2885$. [CrossRef] [PubMed]

16. Sunrice-Australia. Sunrice Annual Report 2016. Available online: https://www.sunrice.com.au/media/ 577307/ sunrice-annual-report-2016.pdf (accessed on 2 March 2018).

17. Canegrowers. Canegrowers Annual Report 2015/16. Available online: http://www.canegrowers.com.au/ icms_docs/271105_canegrowers-annual-report-2015-16.pdf (accessed on 2 March 2018).

18. Cotton-Australia. Australian Cotton Industry Overview. Available online: http:/ / cottonaustralia.com.au/ cotton-library/fact-sheets / cotton-fact-file-the-australian-cotton-industry (accessed on 2 March 2018).

19. RuralBank. Australian Crop Update 2016. Available online: https:/ / www.ruralfinance.com.au/uploads / aga_documents / crop-report-2016.pdf (accessed on 2 March 2018).

20. Belder, P.; Spiertz, J.H.J.; Bouman, B.A.M.; Lu, G.; Tuong, T.P. Nitrogen economy and water productivity of lowland rice under water-saving irrigation. Field Crop Res. 2005, 93, 169-185. [CrossRef]

21. Hu, P.; Ouyang, Y.; Wu, L.; Shen, L.; Luo, Y.; Christie, P. Effects of water management on arsenic and cadmium speciation and accumulation in an upland rice cultivar. J. Environ. Sci. 2015, 27, $225-231$. [CrossRef] [PubMed]

22. Eranki, P.L.; El-Shikha, D.; Hunsaker, D.J.; Bronson, K.F.; Landis, A.E. A comparative life cycle assessment of flood and drip irrigation for guayule rubber production using experimental field data. Ind. Crop Prod. 2017, 99, 97-108. [CrossRef]

23. Moreno-Jiménez, E.; Meharg, A.A.; Smolders, E.; Manzano, R.; Becerra, D.; Sánchez-Llerena, J.; Albarrán, Á.; López-Piñero, A. Sprinkler irrigation of rice fields reduces grain arsenic but enhances cadmium. Sci. Total Environ. 2014, 485-486, 468-473. [CrossRef] [PubMed]

24. Borin, J.B.M.; Carmona, F.d.C.; Anghinoni, I.; Martins, A.P.; Jaeger, I.R.; Marcolin, E.; Hernandes, G.C.; Camargo, E.S. Soil solution chemical attributes, rice response and water use efficiency under different flood irrigation management methods. Agric. Water Manag. 2016, 176, 9-17. [CrossRef]

25. Kijne, J.W. Abiotic stress and water scarcity: Identifying and resolving conflicts from plant level to global level. Field Crop Res. 2006, 97, 3-18. [CrossRef]

26. Bankaji, I.; Sleimi, N.; López-Climent, M.F.; Perez-Clemente, R.M.; Gomez-Cadenas, A. Effects of Combined Abiotic Stresses on Growth, Trace Element Accumulation, and Phytohormone Regulation in Two Halophytic Species. J. Plant Growth Regul. 2014, 33, 632-643. [CrossRef]

27. He, Z.L.; Yang, X.E.; Stoffella, P.J. Trace elements in agroecosystems and impacts on the environment. J. Trace Elem. Med. Biol. 2005, 19, 125-140. [CrossRef] [PubMed]

28. Pan, Y.; Bonten, L.T.C.; Koopmans, G.F.; Song, J.; Luo, Y.; Temminghoff, E.J.M.; Comans, R.N.J. Solubility of trace metals in two contaminated paddy soils exposed to alternating flooding and drainage. Geoderma 2016, 261, 59-69. [CrossRef]

29. Gao, X.; Hoffland, E.; Stomph, T.; Grant, C.A.; Zou, C.; Zhang, F. Improving zinc bioavailability in transition from flooded to aerobic rice. A review. Agron. Sustain. Dev. 2012, 32, 465-478. [CrossRef]

30. Du Laing, G.; Rinklebe, J.; Vandecasteele, B.; Meers, E.; Tack, F.M.G. Trace metal behaviour in estuarine and riverine floodplain soils and sediments: A review. Sci. Total Environ. 2009, 407, 3972-3985. [CrossRef] [PubMed]

31. Kabata-Pendias, A. Soil-plant transfer of trace elements-An environmental issue. Geoderma 2004, 122, 143-149. [CrossRef]

32. Halili, J.; Bislimi, K.; Mazreku, I.; Behluli, A.; Osmani, F.; Maloku, A.; Halili, F. Translocation of some heavy metals from soil in fruit-wines of the grape vine vineyards of Rahovec. Int. Multidiscip. Sci. Geoconf. SGEM 2013, 1, 531.

33. Nessa, F.; Jewel, M.A.H. Analysis of soil nutrient and heavy metal concentration in agricultural land of Zirani industrial area, Savar, Dhaka. Int. J. Innov. Sci. Res. 2014, 10, 90-98.

34. Broadley, M.; Brown, P.; Cakmak, I.; Rengel, Z.; Zhao, F. Function of nutrients: Micronutrients. In Marschner's Mineral Nutrition of Higher Plants, 3rd ed.; Elsevier: Amsterdam, The Netherlands, 2012; pp. 191-248. 
35. Kabata-Pendias, A.; Mukherjee, A.B. Trace Elements from Soil to Human; Springer: Berlin/Heidelberg, Germany, 2007.

36. Hänsch, R.; Mendel, R.R. Physiological functions of mineral micronutrients ( $\mathrm{Cu}, \mathrm{Zn}, \mathrm{Mn}, \mathrm{Fe}, \mathrm{Ni}, \mathrm{Mo}, \mathrm{B}, \mathrm{Cl})$. Curr. Opin. Plant Biol. 2009, 12, 259-266. [CrossRef] [PubMed]

37. Yadav, S.K. Heavy metals toxicity in plants: An overview on the role of glutathione and phytochelatins in heavy metal stress tolerance of plants. S. Afr. J. Bot. 2010, 76, 167-179. [CrossRef]

38. Saenen, E.; Horemans, N.; Vanhoudt, N.; Vandenhove, H.; Biermans, G.; Van Hees, M.; Wannijn, J.; Vangronsveld, J.; Cuypers, A. Effects of $\mathrm{pH}$ on uranium uptake and oxidative stress responses induced in Arabidopsis thaliana. Environ. Toxicol. Chem. 2013, 32, 2125-2133. [CrossRef] [PubMed]

39. Rogers, H.; Munné-Bosch, S. Production and scavenging of reactive oxygen species and redox signaling during leaf and flower senescence: Similar but different. Plant Physiol. 2016, 171, 1560-1568. [CrossRef] [PubMed]

40. Baxter, A.; Mittler, R.; Suzuki, N. ROS as key players in plant stress signalling. J. Exp. Bot. 2014, 65, 1229-1240. [CrossRef] [PubMed]

41. Choudhury, S.; Panda, P.; Sahoo, L.; Panda, S.K. Reactive oxygen species signaling in plants under abiotic stress. Plant Signal. Behav. 2013, 8, e23681. [CrossRef] [PubMed]

42. Gill, S.S.; Tuteja, N. Reactive oxygen species and antioxidant machinery in abiotic stress tolerance in crop plants. Plant Physiol. Biochem. 2010, 48, 909-930. [CrossRef] [PubMed]

43. Dizdaroglu, M.; Jaruga, P. Mechanisms of free radical-induced damage to DNA. Free Radic. Res. 2012, 46, 382-419. [CrossRef] [PubMed]

44. Bandyopadhyay, U.; Das, D.; Banerjee, R.K. Reactive oxygen species: Oxidative damage and pathogenesis. Curr. Sci. India 1999, 77, 658-666.

45. Cramer, G.R.; Urano, K.; Delrot, S.; Pezzotti, M.; Shinozaki, K. Effects of abiotic stress on plants: A systems biology perspective. BMC Plant Biol. 2011, 11, 163. [CrossRef] [PubMed]

46. Halford, N.G.; Curtis, T.Y.; Chen, Z.; Huang, J. Effects of abiotic stress and crop management on cereal grain composition: Implications for food quality and safety. J. Exp. Bot. 2014, 66, 1145-1156. [CrossRef] [PubMed]

47. Nitschke, S.; Cortleven, A.; Iven, T.; Feussner, I.; Havaux, M.; Riefler, M.; Schmülling, T. Circadian Stress Regimes Affect the Circadian Clock and Cause Jasmonic Acid-Dependent Cell Death in Cytokinin-Deficient Arabidopsis Plants. Plant Cell 2016, 28, 1616-1639. [CrossRef] [PubMed]

48. Hu, W.; Ding, Z.; Tie, W.; Yan, Y.; Liu, Y.; Wu, C.; Liu, J.; Wang, J.; Peng, M.; Xu, B.; et al. Comparative physiological and transcriptomic analyses provide integrated insight into osmotic, cold, and salt stress tolerance mechanisms in banana. Sci. Rep. 2017, 7, 43007. [CrossRef] [PubMed]

49. Tsabari, O.; Nevo, R.; Meir, S.; Carrillo, L.R.; Kramer, D.M.; Reich, Z. Differential effects of ambient or diminished $\mathrm{CO}_{2}$ and $\mathrm{O}_{2}$ levels on thylakoid membrane structure in light-stressed plants. Plant J. 2015, 81, 884-894. [CrossRef] [PubMed]

50. Chinnusamy, V.; Zhu, J.; Zhu, J.-K. Cold stress regulation of gene expression in plants. Trend Plant Sci. 2007, 12, 444-451. [CrossRef] [PubMed]

51. Silva, E.N.; Ferreira-Silva, S.L.; Fontenele, A.d.V.; Ribeiro, R.V.; Viégas, R.A.; Silveira, J.A.G. Photosynthetic changes and protective mechanisms against oxidative damage subjected to isolated and combined drought and heat stresses in Jatropha curcas plants. J. Plant Physiol. 2010, 167, 1157-1164. [CrossRef] [PubMed]

52. Shao, H.-B.; Chu, L.-Y.; Jaleel, C.A.; Zhao, C.-X. Water-deficit stress-induced anatomical changes in higher plants. C. R. Biol. 2008, 331, 215-225. [CrossRef] [PubMed]

53. Osakabe, Y.; Arinaga, N.; Umezawa, T.; Katsura, S.; Nagamachi, K.; Tanaka, H.; Ohiraki, H.; Yamada, K.; Seo, S.-U.; Abo, M.; et al. Osmotic stress responses and plant growth controlled by potassium transporters in Arabidopsis. Plant Cell 2013, 25, 609-624. [CrossRef] [PubMed]

54. Aziz, A.; Larher, F. Osmotic stress induced changes in lipid composition and peroxidation in leaf discs of Brassica napus L. J. Plant Physiol. 1998, 153, 754-762. [CrossRef]

55. Grybos, M.; Davranche, M.; Gruau, G.; Petitjean, P. Is trace metal release in wetland soils controlled by organic matter mobility or Fe-oxyhydroxides reduction? J. Colloid Interface Sci. 2007, 314, 490-501. [CrossRef] [PubMed]

56. Emamverdian, A.; Ding, Y.; Mokhberdoran, F.; Xie, Y. Heavy metal stress and some mechanisms of plant defense response. Sci. World J. 2015, 2015. [CrossRef] [PubMed] 
57. Inagaki, Y.; Cong, V.H.; Sakakibara, Y. Identification and application of Phyto-Fenton reactions. Chemosphere 2016, 144, 1443-1450. [CrossRef] [PubMed]

58. Baker, J.; Sitthisak, S.; Sengupta, M.; Johnson, M.; Jayaswal, R.; Morrissey, J.A. Copper stress induces a global stress response in Staphylococcus aureus and represses sae and agr expression and biofilm formation. Appl. Environ. Microbiol. 2010, 76, 150-160. [CrossRef]

59. Ward, S.K.; Hoye, E.A.; Talaat, A.M. The global responses of Mycobacterium tuberculosis to physiological levels of copper. J. Bacteriol. 2008, 190, 2939-2946. [CrossRef] [PubMed]

60. Teitzel, G.M.; Geddie, A.; Susan, K.; Kirisits, M.J.; Whiteley, M.; Parsek, M.R. Survival and growth in the presence of elevated copper: Transcriptional profiling of copper-stressed Pseudomonas aeruginosa. J. Bacteriol. 2006, 188, 7242-7256. [CrossRef] [PubMed]

61. Richards, S.L.; Wilkins, K.A.; Swarbreck, S.M.; Anderson, A.A.; Habib, N.; Smith, A.G.; McAinsh, M.; Davies, J.M. The hydroxyl radical in plants: From seed to seed. J. Exp. Bot. 2015, 66, 37-46. [CrossRef] [PubMed]

62. Turner, A.G.; Cheryl-lynn, Y.O.; Walker, M.J.; Djoko, K.Y.; McEwan, A.G. Transition Metal Homeostasis in Streptococcus pyogenes and Streptococcus pneumoniae. Adv. Microb. Physiol. 2017, 70, 123-191. [PubMed]

63. Pandey, N.; Pathak, G.C.; Pandey, D.K.; Pandey, R. Heavy metals, Co, Ni, Cu, Zn and Cd, produce oxidative damage and evoke differential antioxidant responses in spinach. Braz. J. Plant Physiol. 2009, 21, $103-111$. [CrossRef]

64. Leskova, A.; Giehl, R.F.H.; Hartmann, A.; Fargasová, A.; von Wirén, N. Heavy metals induce iron-deficiency responses at different hierarchic and regulatory levels. Plant Physiol. 2017, 174, 1-46. [CrossRef] [PubMed]

65. Soetan, K.; Olaiya, C.; Oyewole, O. The importance of mineral elements for humans, domestic animals and plants-A review. Afr. J. Food Sci. 2010, 4, 200-222.

66. Bordo, D.; Djinovic, K.; Bolognesi, M. Conserved Patterns in the Cu, Zn Superoxide Dismutase Family. J. Mol. Biol. 1994, 238, 366-386. [CrossRef] [PubMed]

67. Bowler, C.; Van Camp, W.; Van Montagu, M.; Inze, D.; Asada, K. Superoxide dismutase in plants. CRC Crit. Rev. Plant Sci. 1994, 13, 199-218. [CrossRef]

68. Kanematsu, S.; Asada, K. Ferric and manganic superoxide dismutases in Euglena gracilis. Biochem. Biophys. 1979, 195, 535-545. [CrossRef]

69. Noctor, G.; Reichheld, J.-P.; Foyer, C.H. ROS-related redox regulation and signaling in plants. Semin. Cell Dev. Biol. 2017. [CrossRef] [PubMed]

70. Zamocky, M.; Furtmüller, P.G.; Obinger, C. Evolution of catalases from bacteria to humans. Antioxid. Redox Signal. 2008, 10, 1527-1548. [CrossRef] [PubMed]

71. Jones, P.; Suggett, A. The catalase-hydrogen peroxide system. Kinetics of catalatic action at high substrate concentrations. Biochem. J. 1968, 110, 617-620. [CrossRef] [PubMed]

72. Chandlee, J.M.; Tsaftaris, A.S.; Scandalios, J.G. Purification and partial characterization of three genetically defined catalases of maize. Plant Sci. Lett. 1983, 29, 117-131. [CrossRef]

73. Dat, J.; Vandenabeele, S.; Vranová, E.; Van Montagu, M.; Inzé, D.; Van Breusegem, F. Dual action of the active oxygen species during plant stress responses. Cell. Mol. Life Sci. 2000, 57, 779-795. [CrossRef] [PubMed]

74. Du, Y.Y.; Wang, P.C.; Chen, J.; Song, C.P. Comprehensive functional analysis of the catalase gene family in Arabidopsis thaliana. J. Integr. Plant Biol. 2008, 50, 1318-1326. [CrossRef] [PubMed]

75. Zhu, J.-K. Regulation of ion homeostasis under salt stress. Curr. Opin. Plant Biol. 2003, 6, 441-445. [CrossRef]

76. Rieuwerts, J.S.; Thornton, I.; Farago, M.E.; Ashmore, M.R. Factors influencing metal bioavailability in soils: Preliminary investigations for the development of a critical loads approach for metals. Chem. Speciat. Bioavailab. 1998, 10, 61-75. [CrossRef]

77. Brallier, S.; Harrison, R.; Henry, C.; Dongsen, X. Liming effects on availability of Cd, Cu, Ni and Zn in a soil amended with sewage sludge 16 years previously. Water Air Soil Pollut. 1996, 86, 195-206. [CrossRef]

78. Aquilano, K.; Baldelli, S.; Ciriolo, M.R. Glutathione: New roles in redox signaling for an old antioxidant. Front. Pharm. 2014, 5, 196. [CrossRef] [PubMed]

79. Ahuja, I.; de Vos, R.C.; Bones, A.M.; Hall, R.D. Plant molecular stress responses face climate change. Trend Plant Sci. 2010, 15, 664-674. [CrossRef] [PubMed]

80. Grover, M.; Ali, S.Z.; Sandhya, V.; Rasul, A.; Venkateswarlu, B. Role of microorganisms in adaptation of agriculture crops to abiotic stresses. World J. Microbiol. Biotechnol. 2011, 27, 1231-1240. [CrossRef] 
81. Sánchez-Cañizares, C.; Jorrín, B.; Poole, P.S.; Tkacz, A. Understanding the holobiont: The interdependence of plants and their microbiome. Curr. Opin. Microbiol. 2017, 38, 188-196. [CrossRef] [PubMed]

82. Glick, B.R.; Penrose, D.M.; Li, J. A model for the lowering of plant ethylene concentrations by plant growth-promoting bacteria. J. Theor. Biol. 1998, 190, 63-68. [CrossRef] [PubMed]

83. Ambrosini, A.; de Souza, R.; Passaglia, L.M. Ecological role of bacterial inoculants and their potential impact on soil microbial diversity. Plant Soil 2016, 400, 193-207. [CrossRef]

84. Howard, J.B.; Rees, D.C. Structural basis of biological nitrogen fixation. Chem. Rev. 1996, 96, $2965-2982$. [CrossRef] [PubMed]

85. Burd, G.I.; Dixon, D.G.; Glick, B.R. Plant growth-promoting bacteria that decrease heavy metal toxicity in plants. Can. J. Microbiol. 2000, 46, 237-245. [CrossRef] [PubMed]

86. Rodríguez, H.; Fraga, R.; Gonzalez, T.; Bashan, Y. Genetics of phosphate solubilization and its potential applications for improving plant growth-promoting bacteria. Plant Soil 2006, 287, 15-21. [CrossRef]

87. Kuklinsky-Sobral, J.; Araújo, W.L.; Mendes, R.; Geraldi, I.O.; Pizzirani-Kleiner, A.A.; Azevedo, J.L. Isolation and characterization of soybean-associated bacteria and their potential for plant growth promotion. Environ. Microbiol. 2004, 6, 1244-1251. [CrossRef] [PubMed]

88. Lee, J.-S.; Heo, Y.-J.; Lee, J.K.; Cho, Y.-H. KatA, the major catalase, is critical for osmoprotection and virulence in Pseudomonas aeruginosa PA14. Infect. Immun. 2005, 73, 4399-4403. [CrossRef] [PubMed]

89. Jamet, A.; Sigaud, S.; Van de Sype, G.; Puppo, A.; Hérouart, D. Expression of the bacterial catalase genes during Sinorhizobium meliloti-Medicago sativa symbiosis and their crucial role during the infection process. Mol. Plant Microbe Interact. 2003, 16, 217-225. [CrossRef] [PubMed]

90. Alhasawi, A.; Castonguay, Z.; Appanna, N.D.; Auger, C.; Appanna, V.D. Glycine metabolism and anti-oxidative defence mechanisms in Pseudomonas fluorescens. Microbiol. Res. 2015, 171, 26-31. [CrossRef] [PubMed]

91. Bihani, S.C.; Chakravarty, D.; Ballal, A. KatB, a cyanobacterial Mn-catalase with unique active site configuration: Implications for enzyme function. Free Radic. Biol. Med. 2016, 93, 118-129. [CrossRef] [PubMed]

92. Chakravarty, D.; Banerjee, M.; Bihani, S.C.; Ballal, A. A salt-inducible Mn-catalase (KatB) protects cyanobacterium from oxidative stress. Plant Physiol. 2015, 175, 1632. [CrossRef] [PubMed]

93. Jamet, A.; Mandon, K.; Puppo, A.; Hérouart, D. $\mathrm{H}_{2} \mathrm{O}_{2}$ is required for optimal establishment of the Medicago sativa/Sinorhizobium meliloti symbiosis. J. Bacteriol. 2007, 189, 8741-8745. [CrossRef] [PubMed]

94. Kohler, J.; Hernández, J.A.; Caravaca, F.; Roldán, A. Plant-growth-promoting rhizobacteria and arbuscular mycorrhizal fungi modify alleviation biochemical mechanisms in water-stressed plants. Funct. Plant Biol. 2008, 35, 141-151. [CrossRef]

95. Berger, S.; Sinha, A.K.; Roitsch, T. Plant physiology meets phytopathology: Plant primary metabolism and plant-pathogen interactions. J. Exp. Bot. 2007, 58, 4019-4026. [CrossRef] [PubMed]

96. Orozco-Cárdenas, M.L.; Narváez-Vásquez, J.; Ryan, C.A. Hydrogen peroxide acts as a second messenger for the induction of defense genes in tomato plants in response to wounding, systemin, and methyl jasmonate. Plant Cell 2001, 13, 179-191. [CrossRef] [PubMed]

97. Tondo, M.L.; Delprato, M.L.; Kraiselburd, I.; Fernández Zenoff, M.V.; Farías, M.E.; Orellano, E.G. $\mathrm{KatG}$, the bifunctional catalase of Xanthomonas citri subsp. citri, responds to hydrogen peroxide and contributes to epiphytic survival on citrus leaves. PLoS ONE 2016, 11, e0151657. [CrossRef] [PubMed]

98. Sun, D.; Crowell, S.A.; Harding, C.M.; De Silva, P.M.; Harrison, A.; Fernando, D.M.; Mason, K.M.; Santana, E.; Loewen, P.C.; Kumar, A.; et al. KatG and KatE confer Acinetobacter resistance to hydrogen peroxide but sensitize bacteria to killing by phagocytic respiratory burst. Life Sci. 2016, 148, 31-40. [CrossRef] [PubMed]

99. Brossier, F.; Boudinet, M.; Jarlier, V.; Petrella, S.; Sougakoff, W. Comparative study of enzymatic activities of new KatG mutants from low- and high-level isoniazid-resistant clinical isolates of Mycobacterium tuberculosis. Tuberculosis 2016, 100, 15-24. [CrossRef] [PubMed]

100. Behnsen, J.; Raffatellu, M. Siderophores: More than stealing iron. MBio 2016, 7, e01906. [CrossRef] [PubMed]

101. Premachandra, D.; Hudek, L.; Brau, L. Bacterial modes of action for enhancing of plant growth. J. Biotechnol. Biomater. 2016, 6, 1-8. [CrossRef]

102. Hudek, L.; Rai, S.; Michalczyk, A.; Rai, L.; Neilan, B.; Ackland, M.L. Physiological metal uptake by Nostoc punctiforme. Biometals 2012, 25, 893-903. [CrossRef] [PubMed] 
103. Ma, Z.; Jacobsen, F.E.; Giedroc, D.P. Coordination chemistry of bacterial metal transport and sensing. Chem. Rev. 2009, 109, 4644-4681. [CrossRef] [PubMed]

104. Mishra, J.; Singh, R.; Arora, N.K. Alleviation of Heavy Metal Stress in Plants and Remediation of Soil by Rhizosphere Microorganisms. Front. Microbiol. 2017, 8, 1706. [CrossRef] [PubMed]

105. Mejáre, M.; Bülow, L. Metal-binding proteins and peptides in bioremediation and phytoremediation of heavy metals. Trends Biotechnol. 2001, 19, 67-73. [CrossRef]

106. Islam, F.; Yasmeen, T.; Ali, Q.; Mubin, M.; Ali, S.; Arif, M.S.; Hussain, S.; Riaz, M.; Abbas, F. Copper-resistant bacteria reduces oxidative stress and uptake of copper in lentil plants: Potential for bacterial bioremediation. Environ. Sci. Pollut. Res. Int. 2016, 23, 220-233. [CrossRef] [PubMed]

107. Vivas, A.; Biró, B.; Ruíz-Lozano, J.M.; Barea, J.M.; Azcón, R. Two bacterial strains isolated from a Zn-polluted soil enhance plant growth and mycorrhizal efficiency under Zn-toxicity. Chemosphere 2006, 62, 1523-1533. [CrossRef] [PubMed]

108. Radzki, W.; Gutierrez Mañero, F.J.; Algar, E.; Lucas García, J.A.; García-Villaraco, A.; Ramos Solano, B. Bacterial siderophores efficiently provide iron to iron-starved tomato plants in hydroponics culture. Antonie Leeuwenhoek 2013, 104, 321-330. [CrossRef] [PubMed]

109. Sharma, A.; Johri, B.N. Growth promoting influence of siderophore-producing Pseudomonas strains GRP3A and PRS9 in maize (Zea mays L.) under iron limiting conditions. Microbiol. Res. 2003, 158, 243-248. [CrossRef] [PubMed]

110. Kołodyńska, D. Application of a new generation of complexing agents in removal of heavy metal ions from different wastes. Environ. Sci. Pollut. Res. Int. 2013, 20, 5939-5949. [CrossRef] [PubMed]

111. Grčman, H.; Velikonja-Bolta, Š.; Vodnik, D.; Kos, B.; Leštan, D. EDTA enhanced heavy metal phytoextraction: Metal accumulation, leaching and toxicity. Plant Soil 2001, 235, 105-114. [CrossRef]

112. Hudek, L.; Enez, A.; Webster, W.A.J.; Premachandra, D.; Bräu, L. Inoculation of Brassica napus L. (canola) with Pseudomonas fluorescens DUS1-27 leads to inhibition of plant growth due to accumulation of hydrogen peroxide. Plant Soil 2018. [CrossRef]

(C) 2018 by the authors. Licensee MDPI, Basel, Switzerland. This article is an open access article distributed under the terms and conditions of the Creative Commons Attribution (CC BY) license (http:/ / creativecommons.org/licenses/by/4.0/). 